\title{
Seasonal Variation of Heavy Metals in Pre and Post-Treatment Sites of Waste Water Treatment Plant at River Narmada, Jabalpur Madhya Pradesh, India
}

\author{
Anjana Sharma ${ }^{1 *}$, Preeti Bala Pal ${ }^{1}$ and Meenal Budholia Rehman ${ }^{2}$
}

${ }^{1}$ Bacteriology Laboratory, Department of P. G. Studies and Research in Biological Science, Rani Durgavati University, Jabalpur, Madhya Pradesh, India

${ }^{2}$ Department of Botany, Mata Gujri Women's college, Jabalpur (M.P), India

*Corresponding author

\section{A B S T R A C T}

\begin{tabular}{|l|}
\hline K e y w o r d s \\
Wastewater, Heavy \\
metal, Seasonal variation, \\
$\begin{array}{l}\text { River Narmada, Atomic } \\
\text { Absorption } \\
\text { Spectrophotometer (AAS) }\end{array}$ \\
\hline Article Info \\
\hline $\begin{array}{l}\text { Accepted: } \\
\text { 04 February } 2018 \\
\text { Available Online: } \\
\text { 10 March 2018 }\end{array}$ \\
\hline \hline
\end{tabular}

Introduction

The growing problem of water scarcity has significant negative influence on economic development, human livelihoods, and environmental quality throughout the world. Rapid urbanization and industrialization releases enormous volumes of wastewater, which is increasingly utilized as a valuable resource for irrigation in urban and peri-urban agriculture. It drives significant economic activity, supports countless livelihoods particularly those of poor farmers, and substantially changes the water quality of natural water bodies (Marshall et al., 2007). Waste water treatment plants (WWTP) are supposed to make the municipal sewage compatible for disposal into the environment (surface and underground water bodies or land), to minimize the environmental and health impacts, and to make the sewage fit for recycling and reuse (agricultural and aquacultural uses, municipal and industrial uses (Tarundeep, 2010).

Being non - biodegradable in nature, having long biological half-lives and their potential to accumulate in different body parts these heavy 
metals as considered harmful (Manaham, 2005; Wilson and Pyatt, 2007). Their unwarranted gathering in agricultural land through waste water irrigation may not only consequence in water contamination, but also influence food superiority and safety (Muchuweti et al., 2006). Preceding researches also suggests that heavy metals such as $\mathrm{Pb}, \mathrm{Mn}, \mathrm{Zn}, \mathrm{Cr}, \mathrm{Cu}, \mathrm{Ni}$ and $\mathrm{Fe}$ have carcinogenic or toxic effects on human beings and environment (Trichopoulos, 2001; Turkdogan et al., 2002; Kocasoy and Sahin, 2007).

Jabalpur is the third largest city and one of the major industrial States of Madhya Pradesh. Total Sewage generation of Jabalpur city contributes 143.34 MLD respectively. Nearly all the sewage from Jabalpur city channels through the Khandari Nala entering the basin waterways of Narmada partially treated or untreated, waste totalling 140 (MLD) million litres per day discharge of human waste.

Narmada River originates from Amarkantak and it is the fifth largest west flowing river in the Central Indian peninsula. Narmada being an important source of water for the cities situated around its basin, its water is used for drinking purpose directly therefore, quality and content in water is an important factor that affects mankind (Narmada Valley Development Authority 2002). The basin covers $86 \%$ of Madhya Pradesh. 14\% of Gujarat and 2\% of Maharashtra (Sharma et al., 2009; Sharma and Chaturvedi 2007; Sharma and Khokale 2005, 2006). Jabalpur, Dindori, Mandla, Narsingpur, Hoshangabad are the major cities of M.P. satiated at Narmada bank and most of the water reprimand of these cities fulfil by Narmada River.

Therefore, the present study is aimed to monitor the water quality of River Narmada on the basis of presence of heavy metals as it is the source of drinking water supply for
Jabalpur Municipal Corporation and to evaluate the status of post treatment drinking water quality at the user end during Winter, Summer, Monsoon-Rainy and Post-Monsoon periods. As more information becomes available on the ecological impacts of wastewater discharge, permit limitations are becoming more stringent.

\section{Materials and Methods}

\section{Plant description and study site}

The present waste water treatment plant (Khandari Nala Waste Water Treatment Plant) is situated in Jabalpur, Madhya Pradesh, within the geographical coordinates of $23^{0} 7$, $54 " \mathrm{~N}$ and $79^{\circ} 58^{\prime} 0$ " E (Figure 1). It receives the waste water generated in Jabalpur city. Khandari Nala Waste Water Treatment Plant (WWTP) is designed to treat approximately 28 to 35 MLD. The plant receives domestic sewage, some light industrial wastewater, as well as run-off water and the treatment is based on the phytoremediation system and the final effluent is discharged into the River Narmada. The wastewater samples were collected from the following points of Treatment Plant installed at Khandari Nala. Under the present study, waste water samples were collected from raw sewage and treated water of waste water treatment plant (WWTP) during the period September 2015 to August 2016.

Site 1: Khandari Nala: Untreated Effluent (UE), Site 2: Khandari Nala: Treated Effluent (TE), Site 3: Khandari Nala Discharge in River Narmada: Discharge Point (DP), Site 4: Khandari Nala: Upstream (UP) and Site 5: Khandari Nala: Downstream (DW).

\section{Sample collection}

Waste water samples were collected from the UE, TE, DP, UP and DW point, in glass 
containers, pre-cleaned by washing with nonionic detergents rinsed in tap water, $1: 1$ hydrochloric acid and finally with deionised water in pre-sterilized bottles. The actual samplings were done in midstream by dipping each sample bottle at approximately $20-30 \mathrm{~cm}$ below the water surface, projecting the mouth of the container against the flow direction. The samples were then transported in cooler boxed containing ice to the Bacteriology Laboratory, Department of P. G. Studies and Research in Biological Science, Rani Durgavati University, Jabalpur, Madhya Pradesh, India, stored at $4^{\circ} \mathrm{C}$. Samples were analyzed within $48 \mathrm{~h}$ of collection (APHA, 1998).

\section{Chemicals and sample digestion}

All standard solutions for targeted elements were supplied by Merck Germany with highest purity level (99.98\%). Ultra-pure nitric acid $\left(\mathrm{HNO}_{3}\right)$ was used for sample digestion. All other acids and chemicals were either supra pure or ultra-pure received from Merck Germany or Scharlau Spain. After collection, water samples were filtered through Millipore Filtration Assembly, using $0.45 \mathrm{~mm}$ membrane filter. The filtrate was then acidified with concentrated $\mathrm{HNO}_{3}$ to make a $\mathrm{pH}$ of $<2$. Samples were acidified to $0.24 \mathrm{M}$ with $\mathrm{HNO}_{3}$ (65\% supra pure, Hi-Media) and Samples were subjected to nitric acid digestion according to the EPA guidelines (Shah and Singh 2016). A portion of this solution was taken for required metal determinations.

\section{Heavy metal analysis}

Heavy metals analysis was carried out using AAS (Model Name PinAAcle 900 H). The AAS was calibrated for all the metals and matrixes analyzed were $\mathrm{Pb}, \mathrm{Cr}, \mathrm{Mn}, \mathrm{Ni}, \mathrm{Fe}$, $\mathrm{Cu}$ and $\mathrm{Zn}$ using AAS system by running different concentrations of standard solutions. Average values of three replicates were taken for each determination. All the methods are inhouse validated following analytical conditions for the measurement of the heavy metals in sample using AAS. Chromium, Copper, Iron, Manganese, Nickel, Lead, and Zinc were estimated by acid digestion method using atomic absorption spectrophotometer (APHA, 1998).

\section{Statistical analysis}

The data were statistically analyzed by the means and standard deviations of the heavy metal concentrations in wastewater were calculated.

\section{Results and Discussion}

In the present investigation a total of seven heavy metals were recorded in Khandari Nala which includes Lead, Manganese, Zinc, Chromium, Nickel, Copper and Iron. The average variation of the heavy metals $(\mathrm{Pb}, \mathrm{Mn}$, $\mathrm{Zn}, \mathrm{Cr}, \mathrm{Ni}, \mathrm{Cu}$ and $\mathrm{Fe}$ ) in Khandari Nala and the data collected on these trace heavy metals were analyzed during September 2015 to August 2016, is shown in Figure 2 a, b, c, d, e, $f$ and $g$. Results of evaluated heavy metal parameters of the wastewater treatments plants effluent were compared against WHO and CPCB for effluent discharge seasonally (Winter, Summer, Monsoon Rainy and PostMonsoon seasons). The profiles of the heavy metal analysis of the water samples obtained at the MWWTP are depicted in Figure $2 a, b$, $\mathrm{c}, \mathrm{d}, \mathrm{e}, \mathrm{f}$ and $\mathrm{g}$ respectively. Khandari Nala waste water samples ranged from the $\mathrm{Pb}$ (Lead) from $0.93 \pm 0.06-1.79 \pm 0.32$ for $\mathrm{UE}$; $0.80 \pm 0.06-1.29 \pm 0.60$ for $\mathrm{TE}, 0.70 \pm 0.13-$ $0.99 \pm 0.08$ for DP, $0.83 \pm 0.06-1.24 \pm 0.27$ for UP, and $0.55 \pm 0.10-1.25 \pm 0.45$ for DW. The $\mathrm{Cr}$ (Chromium) in the waste water samples at MWWTP ranged from $0.56 \pm 0.13$ $-0.92 \pm 0.06$ for UE; $0.33 \pm 0.04-0.70 \pm$ 0.04 for TE, $0.16 \pm 0.06-0.50 \pm 0.03$ for $\mathrm{DP}$, $0.74 \pm 0.06-1.02 \pm 0.05$ for UP, and $0.53 \pm$ 
$0.07-0.96 \pm 0.05$ for DW. The Mn (Manganese) in the waste water samples at MWWTP ranged from 6. $31 \pm 0.86-27.00 \pm$ 0.62 for $\mathrm{UE} ; 4.02 \pm 0.56-21.85 \pm 1.52$ for TE, $2.47 \pm 0.47-19.14 \pm 0.44$ for DP, $6.25 \pm$ $0.34-22.91 \pm 0.44$ for UP, and $4.65 \pm 0.52-$ $17.18 \pm 0.71$ for DW. The Ni (Nickel) in the waste water samples at MWWTP ranged from $0.61 \pm 0.04-0.96 \pm 0.06$ for UE; $0.36 \pm 0.05$ $-0.59 \pm 0.24$ for TE, $0.04 \pm 0.01-0.24 \pm$ 0.12 for DP, $0.44 \pm 0.02-0.92 \pm 0.06$ for UP, and $0.58 \pm 0.05-0.86 \pm 0.06$. The Fe (Iron) in the waste water samples at MWWTP ranged from $9.12 \pm 0.51-16.44 \pm 0.68$ for UE; 7.99 $\pm 0.72-13.55 \pm 0.98$ for TE, $5.87 \pm 0.72-$ $12.67 \pm 1.05$ for DP, $6.29 \pm 0.62-16.25 \pm$ 0.71 for UP, and $3.78 \pm 0.55-12.10 \pm 0.38$ for DW.

The $\mathrm{Cu}$ (Copper) in the waste water samples at MWWTP ranged from $0.07 \pm 0.02-1.22 \pm$ 0.38 for UE; $0.12 \pm 0.10-1.07 \pm 0.06$ for TE, $0.10 \pm 0.08-1.01 \pm 0.08$ for DP, $0.27 \pm 0.07$ $-1.40 \pm 0.51$ for UP, and $0.49 \pm 0.05-0.97 \pm$ 0.07 for DW. The Zn (Zinc) in the waste water samples at MWWTP ranged from $1.07 \pm 0.13$ $-2.07 \pm 0.05$ for UE; $0.99 \pm 0.09-1.14 \pm$ 0.13 for TE, $0.64 \pm 0.07-0.98 \pm 0.01$ for DP, $1.05 \pm 0.05-1.99 \pm 0.11$ for UP, and $0.89 \pm$ $0.04-1.17 \pm 0.64$ for DW. The mean concentrations of these heavy metals were observed in Summer, Winter and Rainy season which were much higher than WHO Standard limit for drinking water.

Heavy metals are generally considered to be those elements whose density exceeds 5 g per cubic centimetre Heavy metals cause serious health problems, including reduced growth and development, cancer, organ damage, nervous system damage, and in extreme cases, death may occur. Exposure to some metals, such as mercury and lead, may also cause development of autoimmunity, in which a person's immune system attacks its own cells. This can lead to joint diseases such as rheumatoid arthritis, and diseases of the kidneys, circulatory system, nervous system, and damaging of the fatal brain. At higher doses, heavy metals can cause irreversible brain damage. Children may accumulate more metal as they eat more food than adults. Industrial and Municipal Water untreated: when mixed in river, could be the reason of the presence of these heavy metals in river water. Wastewater regulations were established to minimize human and environmental exposure to hazardous chemicals.

Heavy metals in the sewage water are associated with small scale industries such as colouring, electroplating, metal surface treatments, fabric printing, battery and paints, releasing $\mathrm{Cr}, \mathrm{Fe}, \mathrm{Cu}, \mathrm{Pb}, \mathrm{Zn}, \mathrm{Ni}, \mathrm{Mn}$ and other heavy metals into water channels, which are accessed for drinking and irrigation purposes. Studies on concentration of heavy metals in the wastewater, by various researchers like Singh et al., (2004) have reported lower ranges of $\mathrm{Cr}\left(0.00-0.049 \operatorname{lgml}^{1}\right)$ and $\mathrm{Pb}$ (0.012-0.088 $\left.\operatorname{lgml}^{-1}\right)$, but higher ranges of $\mathrm{Cu}$ $\left(0.00-0.203 \operatorname{lgml}^{-1}\right), \mathrm{Ni}\left(0.01-0.22 \mathrm{lgml}^{-1}\right)$ and $\mathrm{Zn}$ (0.023-0.18 $\left.\mathrm{lgml}^{-1}\right)$ another reports of water samples of Khandari Nala (MWWTP) in the area of Jabalpur receiving treated and untreated sewage water for irrigating the agricultural fields reported by Sharma et al., (2007) shows similar ranges of $\mathrm{Ni}$ and $\mathrm{Zn}$ in irrigation water of river, but $\mathrm{Cu}, \mathrm{Pb}$ and $\mathrm{Cr}$ were two fold higher during the present study which may be due to urbanization. Among the heavy metals, the mean concentration was maximum for $\mathrm{Zn}\left(0.151 \mathrm{mg} \mathrm{l}^{-1}\right)$ and minimum for $\mathrm{Cd}\left(0.02 \mathrm{mg} \mathrm{l}^{-1}\right)$ in the irrigation water from MWWTP. The lower concentrations of heavy metals in the irrigation water may be due to dilution of heavy metals in the water medium, but the continuous application of these treated and untreated wastewater for irrigation resulted into accumulation of heavy metals into the waste water. 
Fig.1 (A) Location of Narmada River basin in India, (B) Jabalpur city, (C) Location of the sampling stations of Khandari Nala, Jabalpur, (M.P.), India

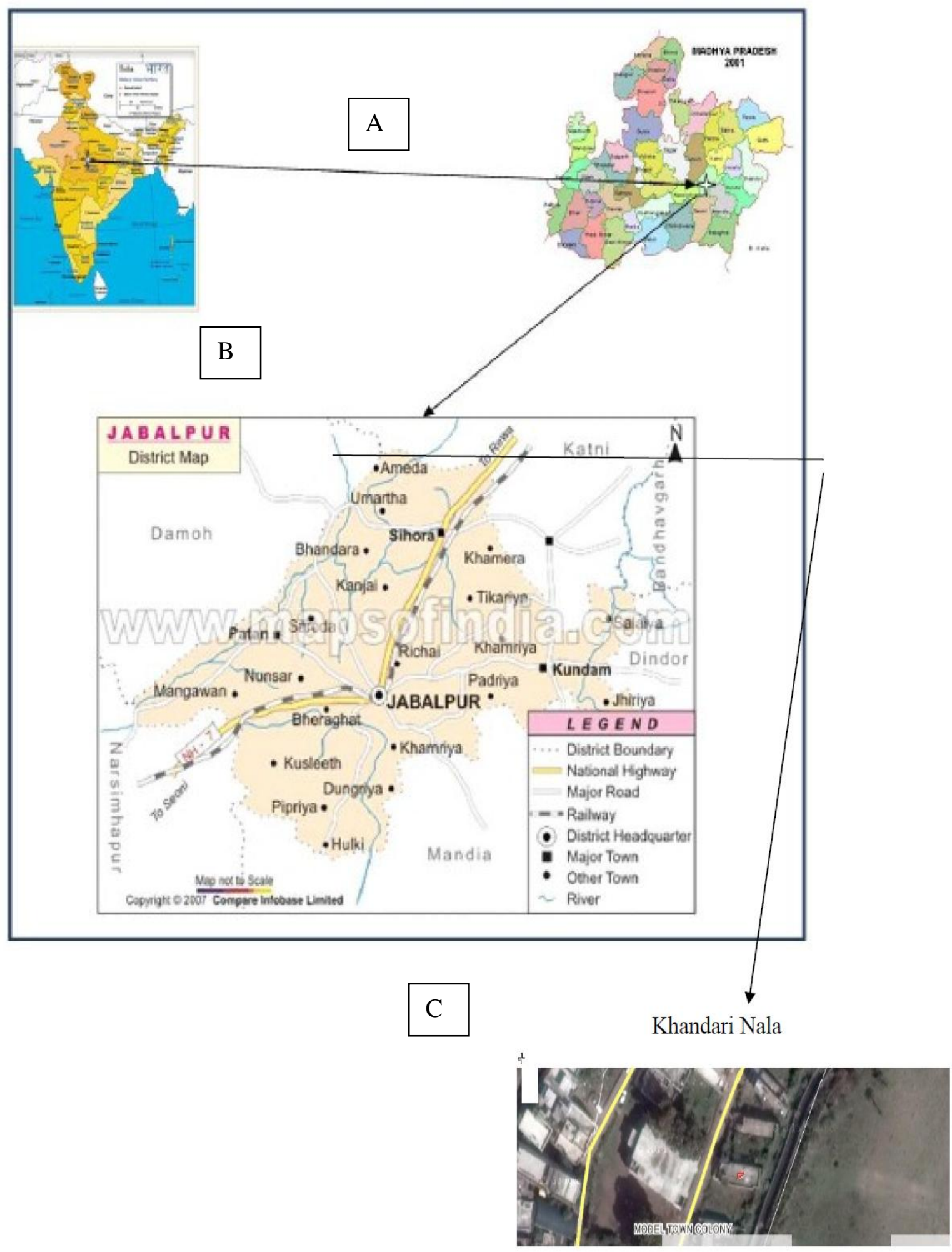


Fig.2 (a, b, c, d, e, f and g) showing Seasonal variation of heavy metals analysis of untreated and treated effluents on municipal waste water treatment plant on Khandari Nala Jabalpur (M.P.)
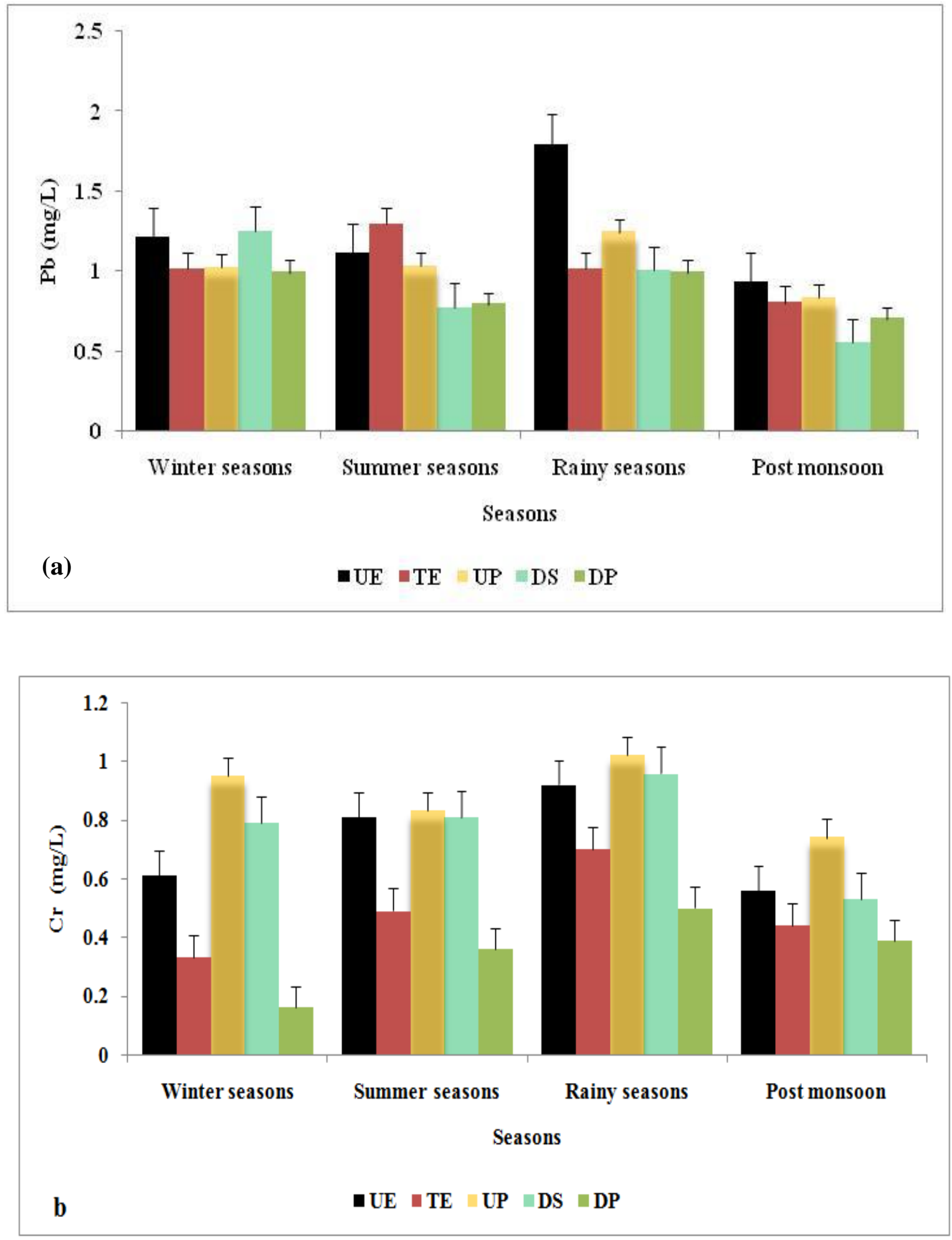

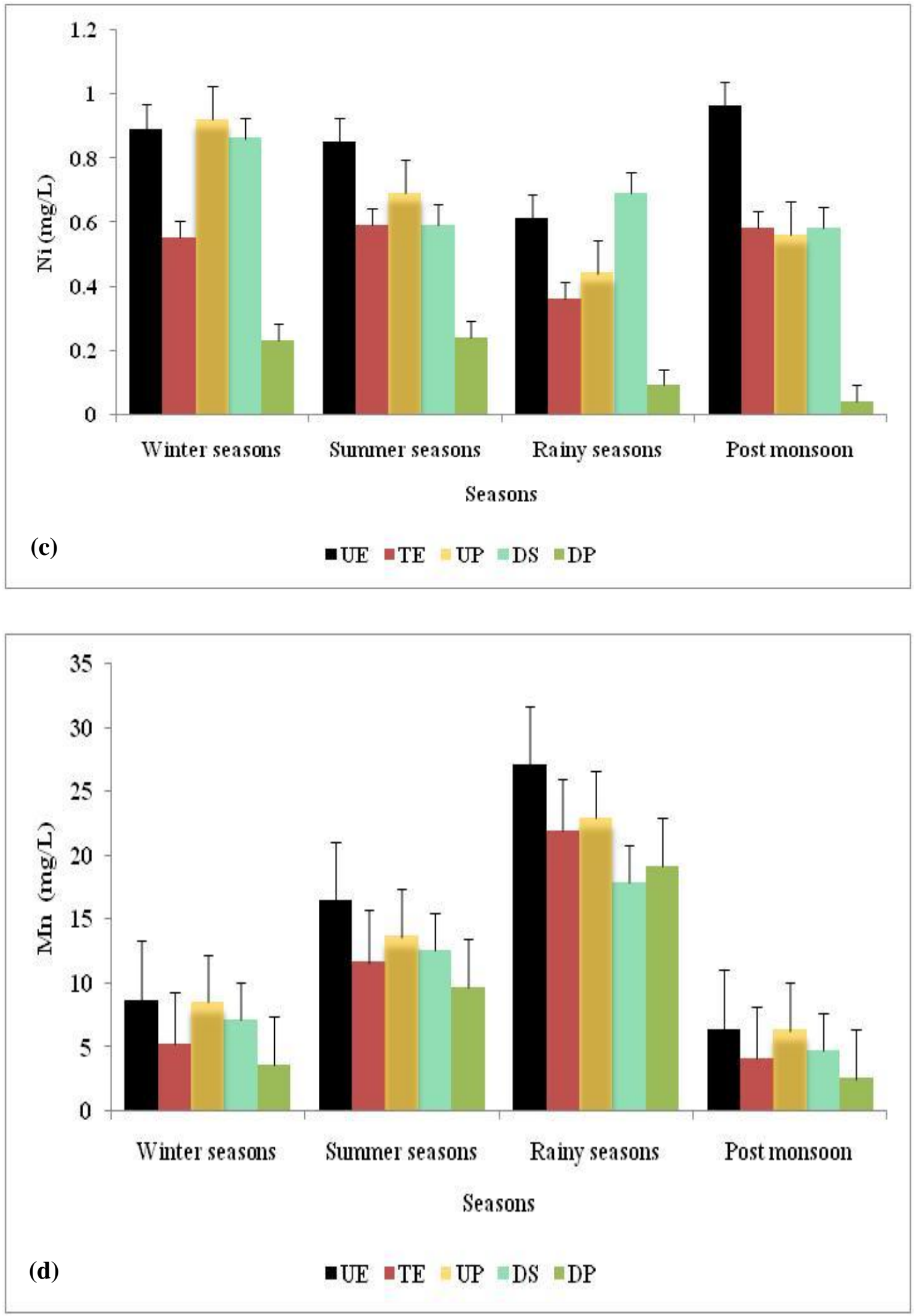

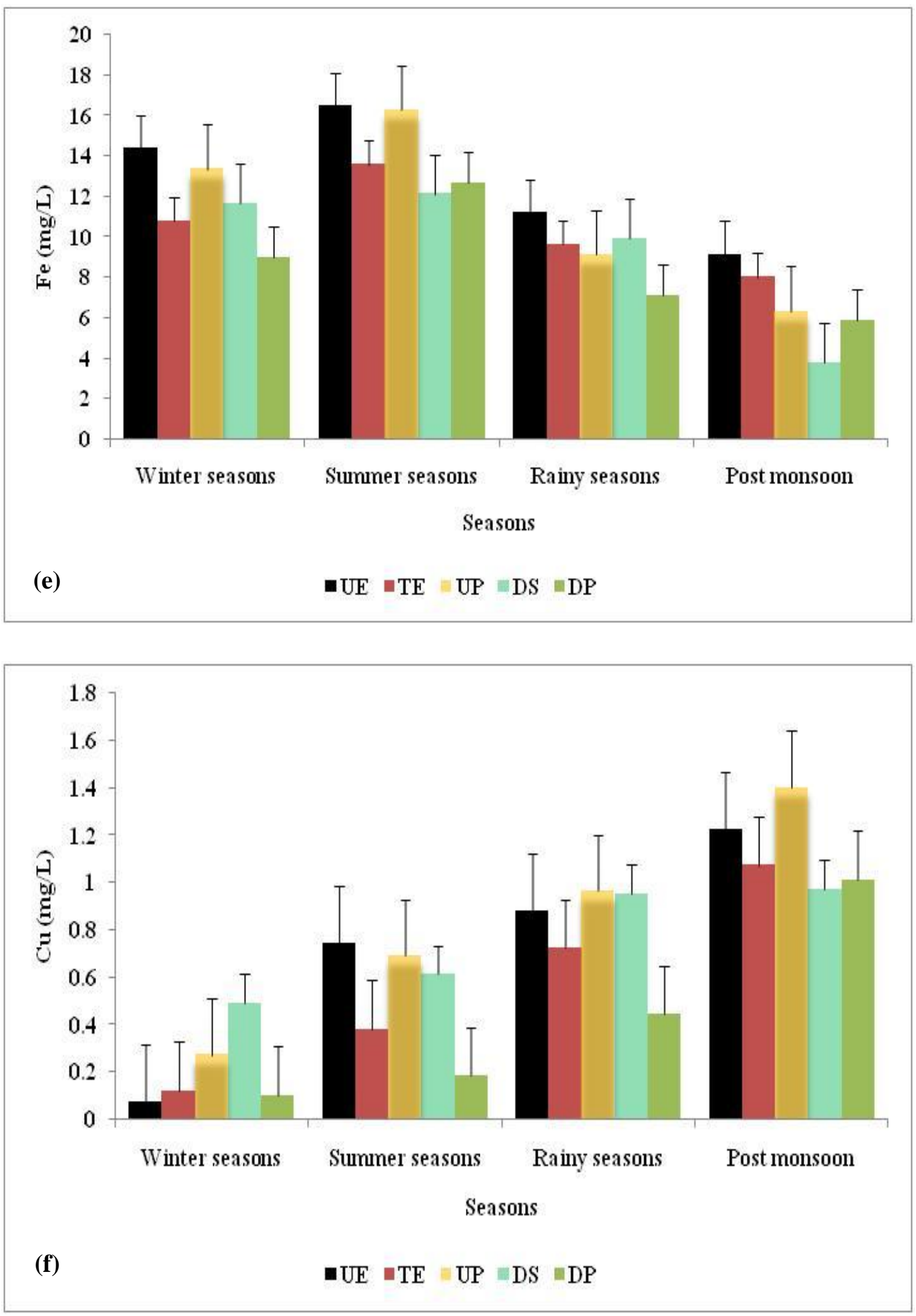


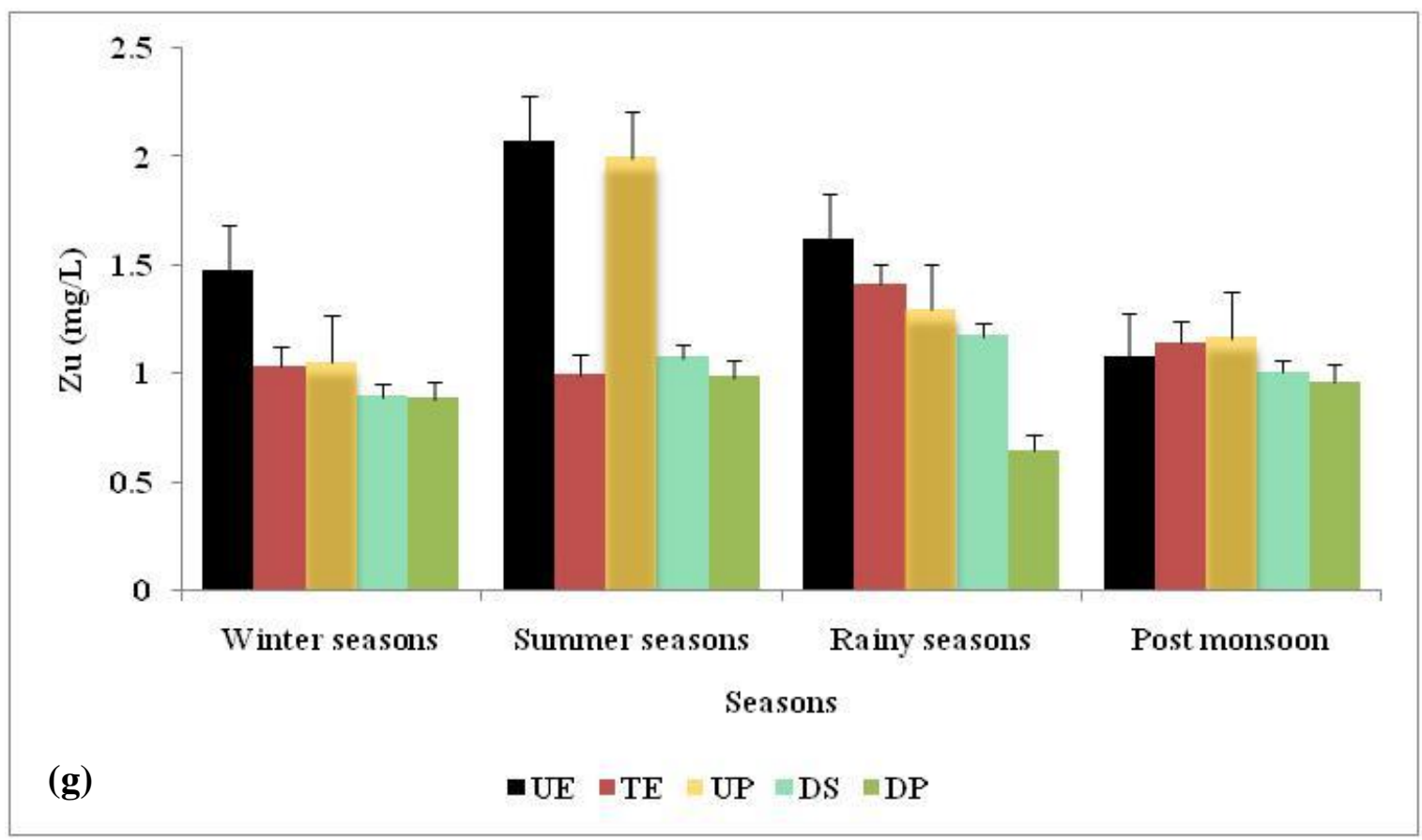

The average concentration of $\mathrm{Pb}, \mathrm{Mn}, \mathrm{Fe}, \mathrm{Zn}$ in water was found to be 0.93-1.79, 6.31 27.00, 9.12-16.44, 1.07- $2.07 \mathrm{mg} / \mathrm{L}$ during Summer, Winter And Rainy season, respectively, which were higher than the drinking water quality standard (WHO, 2017). Considering the toxicity reference values (TRV) proposed by USEPA almost all the heavy metals especially $\mathrm{Cr}$ and $\mathrm{Cu}$ greatly exceeded the limit for safe water, indicated that water from this river at various sites is not safe for drinking and/or cooking (CPCB). The concentration of metals in water varied seasonally, where winter season exhibited higher than summer. The lower concentration of heavy metals during summer might be due to the dilution effect of water (Mohiuddin et al., 2012; Islam et al., 2015; Adamu et al., 2015). Hexavalent form of chromium found in water is generally

carcinogenic if present in higher concentration. This study hold importance on this aspect as chromium was found at higher concentration side, more than WHO recommended level. Another carcinogen: nickel, is also harmful due to its high solubility in water. Biota on the other side is also disturbed by higher concentration of copper. All these metals not only cause organ damage to human, but also are sin to the surrounding environment. These metals disturb the ecological cycle and bioaccumulation of thesis effect biotic and a biotic health (Islam et al., 2014; Koukal et al., 2004).

Heavy metal pollution is a major problem for the Narmada River basin, Jabalpur. In the present study concentrations of $\mathrm{Cr}, \mathrm{Mn}, \mathrm{Fe}$, $\mathrm{Zn}$ and $\mathrm{Pb}$ were higher than the safe values which indicated that the river is polluted by studied heavy metals and might create an adverse effects on this riverine ecosystem. The overall pollution load was remarkably higher in winter than in summer season. This study suggested that point sources of heavy metals in the water should be closely monitored; improvement in conditions and industrial effluent and domestic sewage discharge should be reduced. Rapidly growing of human populations and their activities along the river has increased the pollutant discarded to the Narmada River. The 
transport of toxic metals to the water ways were finally deposited in the area is being accumulated in sediments over the exposure times. The presence of metal ions in surface water will directly affect the natural nutritional value of water ways and continuously affect the aquatic organism populations in the rivers. Over the time, these pollutants will be naturally bio-accumulated and results in bio-magnification in the aquatic organisms. (Lim et al., 2012; Lim et al., 2013; Mokhtar et al., 2015).These pollutants will be transported through the trophic level and finally affects the human health.

This work focused on the determination of $\mathrm{Mn}, \mathrm{Pb}, \mathrm{Cr}, \mathrm{Ni}, \mathrm{Fe}, \mathrm{Cu}$ and $\mathrm{Zn}$ contamination in municipal waste water treatment plant of Khandari Nala. The concentrations of $\mathrm{Mn}, \mathrm{Pb}$, $\mathrm{Cr}, \mathrm{Ni}, \mathrm{Fe}, \mathrm{Cu}$ and $\mathrm{Zn}$ were determined from the treatment plant installed in Khandari Nala using AAS technique. The results showed that the highest concentrations of $\mathrm{Fe}, \mathrm{Mn}, \mathrm{Pb}$ and $\mathrm{Zn}$ were found from the work areas. The total concentrations of heavy metals $(\mathrm{Mn}, \mathrm{Pb}, \mathrm{Cr}$ and $\mathrm{Cd}$ ) in the Khandari Nala waste water were above the critical maximum levels (The standard concentrations reported by WHO for drinking water) above which toxicity is possible. From this point of view, Khandari Nala mixed with river water was contaminated by these metal ion concentration. Therefore treatment requires to remove these metal ion contamination, because the transport flows and the factories are increasing day to day.

This study of heavy metal pollution shows that the levels of various heavy metals in the effluents to be discharged in river Narmada water are far above the acceptable concentrations. Hence, it is necessary that steps should be taken to minimize the metallurgical effluent load deposited into the river. This study suggested that various sources of heavy metals in the water of the river should be closely monitored; industrial effluent and domestic sewage discharge should be treated before mixing to river.

\section{Acknowledgments}

Authors are thankful to Head, Department of P.G. Studies and Research in Biological Science, Rani Durgavati University, Jabalpur, M.P., India, for providing Laboratory facilities and Pollution Control Board Jabalpur, (M.P.) for financial assistance.

\section{References}

Adamu, C.I., Nganje, T.N., Edet, A. 2015. Heavy metal contamination and health risk assessment associated with abandoned barite mines in Cross River State: Southeastern Nigeria. Environ. Nanotechnol. Monit. Manag. 3: 10-21.

American Public Health Association (APHA), 1998. Standard methods for the examination of water and wastewater $\left(16^{\text {th }}\right.$ ed.). Washington, DC: American Public Health Association.

Central Pollution Control Board (CPCB), 1999-2000. Water quality status of Yamuna River, Parivesh Bhawan, Delhi.

Islam, M. S., HAN, S., AHMED, M. K., MASUNAGA, S. 2014. Assessment of trace metal contamination in water and sediment of some Rivers in Bangladesh. J. Wate Environ Technol, 12(2): 109121.

Islam, M.S., Ahmed, M.K., Habibullah-AlMamun, M., Hoque, M.F. 2015. Preliminary assessment of heavy metal contamination in surface sediments from a river in Bangladesh. Environ. Earth Sci. 73: 1837-1848.

Kocasoy, G., Sahin, V. 2007. Heavy metal removal from industrial wastewater by clinoptilolite. J. Environ. Sci. Heal. Part A,42: 2139-2146. 
Koukal, B., Dominik, J., Vignati, D., Arpagaus P., Santiago S., Ouddane, B., Benaabidate, L. 2004. Assessment of water quality and toxicity of polluted Rivers Fez and Sebou in the region of Fez (Morocco). Environ. pollut. 131(1):163-172.

Lim, W.Y., Aris A. Z., Zakaria, M. P. 2012. Spatial Variability of Metals in Surface Water and Sediment in the Langat River and Geochemical Factors That Influence Their Water-Sediment Interactions. Sci. Worl. J. 1-14.

Lim, W.Y., Aris, A. Z., Ismail, T.H.T. 2013. Spatial Geochemical Distribution and Sources of Heavy Metals in the Sediment of Langat River, Western Peninsular Malaysia. Environ Forensics. 14(2):133-145.

Manaham, S.E. 2005. Environmental chemistry. 8 th Edn., Lewis Publisher, Boca Raton, Florida, ISBN 1566706335.

Marshall, F.M., Holden, J., Ghose, C., Chisala, B., Kapungwe, E., Volk, J., Agrawal, M., Agrawal, R., Sharma, R.K., Singh, R.P. 2007. Contaminated Irrigation Water and Food Safety for the Urban and Peri-urban Poor: Appropriate Measures for Monitoring and Control from Field Research in India and Zambia, Incpetion Report DFID Enkar R8160, SPRU, University of Sussex. <www.pollutionandfood.net>.

Mohiuddin, K.M., Otomo, K., Ogawa, Y., Shikazono, N. 2012. Seasonal and spatialdistribution of trace elements in the water and sediments of the Tsurumi riverin Japan. Environ. Monit. Assess. 184: 265-279.

Mokhtar, N. F., Aris, A. Z., Praveena, S. M. 2015. Preliminary study of heavy metal $(\mathrm{Zn}, \mathrm{Pb}, \mathrm{Cr}, \mathrm{Ni})$ contaminations in Langat River estuary, Selangor. Proc. Environm. Scien. 30:285 - 290.
Muchuweti, M., Birkett, J.W., Chinyanga, E., Zvauya, R., Scrimshaw M.D., Lester, J.N. 2006. Heavy metal content of vegetables irrigated with mixture of wastewater and sewage sludge in Zimbabwe: Implications for human health. Agric. Ecosyst. Environ., 112: 41-48.

Narmada Valley Development Authority, 2002. Narmada Basin, Government of Madhya Pradesh.

Shah, A. B., Singh, R. P. 2016. Monitoring of Hazardous Inorganic Pollutants and Heavy Metals in Potable Water at the Source of Supply and Consumers end of a Tropical Urban Municipality. Int. J. Environ. Res., 10(1):149-158.

Sharma, A., Khokale, D. 2006. Distribution and survival of Aeromonas in fresh water system at Jabalpur, in relation to faecal pollution bacteria. Asia. J. Experim Scien, 20(2): 363-368.

Sharma, A., Chaturvedi, A. N. 2007. Population dynamics of Vibrio species in the river Narmada at Jabalpur. Journal of Environmental Biology, 28(4): 747-751.

Sharma, A., Khokale, D. 2005. Biotyping and antibiograms analysis of Aeromonas isolated from river Narmada at Jabalpur (M.P.) India. I. J. Microbiol, 45(4): 265-268

Sharma, R.K., Agrawal M., Marshall F.M. 2007. Heavy metals contamination of soil and vegetables in suburban areas of varanasi. India. Ecotoxicol. Safety, 66: 258-266.

Sharma, R.K., Agrawal, M., Marshall, F.M. 2009. Heavy metal in vegetables collected from production and market sites of tropical urban area of India. Food Chem. Toxicol. 47: 583-591.

Singh, K.P., Mohan, D., Sinha, S., Dalwani, R. 2004. Impact assessment of treated/untreated wastewater toxicants discharged by sewage treatment plants 
on health, agricultural and environmental quality in the wastewater disposal area. Chemosphe, 55:227-255.

Tarundeep G. 2010. Performance monitoring and evaluation of Sewage Treatment Plants based on UASB - Facultative pond $\mathrm{Ph}$. D Thesis, Department of Biotechnology and Environment Sciences Thapar University (Punjab).

Trichopoulos, D. 2001. Epidemiology of cancer. In: Cancer: Principles and Practice of Oncology, De Vita, V.T. (Ed.). Lippincott Company, Philadelphia, ISBN: 0-781-72229-2: 231-258.
Turkdogan, M.K., Kilicel, F., Kara, K., Tuncer, I. 2002. Heavy metals in soil, vegetables and fruits in the endemic upper gastrointestinal cancer region of Turkey. Environ. Toxicol. Pharmacol., 13:175-179.

Wilson, B., Pyatt, F.B. 2007. Heavy metal dispersion, persistence and bioaccumulation around an ancient copper mine situated in anglesey. Uk. Ecotoxicol. Environ. Safety, 66:224231.

World Health Organization (WHO), 2017. Water Quality and Health. Drinking water chlorination - A review of disinfection practices 28 .

\section{How to cite this article:}

Anjana Sharma, Preeti Bala Pal and Meenal Budholia Rehman. 2018. Seasonal Variation of Heavy Metals in Pre and Post-Treatment Sites of Waste Water Treatment Plant at River Narmada, Jabalpur Madhya Pradesh, India. Int.J.Curr.Microbiol.App.Sci. 7(03): 218-229. doi: https://doi.org/10.20546/ijcmas.2018.703.026 